\title{
Comparison of various assays for detection of AFP in differentiating patients with primary hepatocellular carcinoma from controls
}

\author{
SH CHAN, ${ }^{*}+$ SH HENG,* SL YO, $\ddagger$ AND CJ OON \\ From the *WHO Immunology Centre and †Department of Microbiology, Faculty of Medicine, University \\ of Singapore, Singapore, and the $\ddagger$ Medical Unit I, University of Singapore, Singapore General Hospital, \\ Singapore
}

SUMMARY Four assays for the detection of alphafetoprotein (AFP) in the diagnosis of primary hepatocellular carcinoma (HCC) were evaluated. The frequency of AFP detection was compared in $89 \mathrm{HCC}$ patients and in 71 patients with chronic active hepatitis/cirrhosis. Of the four assays, immunodiffusion, counterimmunoelectrophoresis (CIE), supplement CIE, and radioimmunoassay, the best for differentiating patients with HCC from those with chronic active hepatitis and cirrhosis was CIE.

The association of raised levels of alphafetoprotein (AFP) and primary hepatocellular carcinoma (HCC) has been well established, so that a raised AFP level is often used in the diagnosis of primary liver cancer. ${ }^{1}$ However, other liver diseases, for example, cirrhosis, chronic active hepatitis, and viral hepatitis, cause elevated AFP levels, although these levels, in general, are well below those in liver cancer patients.

Assays employed for the detection of AFP vary considerably in sensitivity, ranging from immunodiffusion to radioimmunoassay. The use of insensitive assays for the diagnosis of liver cancer will result in underdiagnosis ('false negatives') whereas with very sensitive assays a 'false positive' diagnosis of other liver disease may be a serious problem. We have used various assays to find the optimal method using AFP for the diagnosis of liver cancer and report the results.

\section{Material and methods}

Blood from 89 patients with HCC, 37 with chronic active hepatitis, 67 with acute viral hepatitis, and 34 cirrhosis patients as well as 56 normal subjects was collected and allowed to clot. The sera were immediately separated and stored at $-20^{\circ} \mathrm{C}$ until tested. The sera were coded and tested in batches. A diagnosis was made after completion of the tests. The various tests were performed on the same sera but some sera

Received for publication 4 January 1980 were exhausted before all the assays had been completed.

AFP was detected in these sera by standard immunodiffusion (ID), counterimmunoelectrophoresis (CIE), and radioimmunoassay (RIA). In addition, a recently described method for AFP detection, the supplement CIE assay, was also used. ${ }^{2}$ Both CIE and supplement CIE assays were performed on lantern glass slides $(10 \times 10 \mathrm{~cm})$. The slides were precoated with $1 \%$ agarose (Behringwerke, Marburg, Germany) in TRIS-EDTA buffer (pH 9.6), dried, and covered to a depth of approximately $2 \mathrm{~mm}$ with a further $22 \mathrm{ml} 1 \%$ agarose/buffer. Fifteen pairs of wells ( $3 \mathrm{~mm}$ well diameter), $4 \mathrm{~mm}$ between each row of wells and between each well pair, were punched towards the cathodal end of the plate using a Perspex template. In the CIE assay, $10 \mu \mathrm{l}$ of anti-AFP (Behringwerke Lot No. 6511E, 0.43 mg/ml, dil. 1:2) were added to the anodal wells and $10 \mu$ of test sera to the cathodal wells by means of a Hamilton syringe. Electrophoresis was carried out at a constant current of $40 \mathrm{~mA}$ per plate $(\sim 200 \mathrm{~V})$ for 60 minutes. In the supplement CIE assay, the method was similar to that of the CIE assay except that electrophoresis was carried out for 10 minutes and then temporarily halted. Five microlitres of a $80 \mathrm{ng} / \mathrm{ml}$ AFP standard were added to the cathodal (antigen) wells, and electrophoresis was continued for another 60 minutes. We have shown previously that $5 \mu \mathrm{l}$ of $80 \mathrm{ng} / \mathrm{ml}$ of AFP will not give precipitin lines by itself. ${ }^{2}$ The plates were routinely examined for 
precipitin lines after being soaked in two changes of saline and one change of distilled water, dried, stained with Amido Black, and destained with methanol-acid. Routinely positive and negative controls were added in every assay. In the initial standardisation of the assays, AFP standards $(0,10$, $30,80,100,320 \mathrm{ng} / \mathrm{ml}$ ) from Dainabbot Laboratories were used. We have shown previously that CIE and supplement CIEassays can detect AFP concentrations of about $80 \mathrm{ng} / \mathrm{ml}$ and $20 \mathrm{ng} / \mathrm{ml}$ respectively. ${ }^{2}$

Radioimmunoassay was performed using commercial kits (Dainabbot, Japan). Three standard deviations above the mean AFP concentration of normal subjects was found to be $16 \mathrm{ng} / \mathrm{ml}$. Therefore a concentration above $16 \mathrm{ng} / \mathrm{ml}$ was considered as abnormal and a positive reaction by RIA.

\section{Results}

The Table summarises the frequency of AFP detection by ID, CIE, supplement CIE, and RIA in patients with $\mathrm{HCC}$, chronic active hepatitis, cirrhosis, acute viral hepatitis, and in normal subjects. None of the normal subjects showed a positive reaction in the four assays. Samples that were positive by ID were always positive by the other assays (when tested), and those that were positive by CIE and supplement CIE were also positive by RIA. Repeated testings of AFP standards in CIE and supplement CIE assays showed consistency of results. Among HCC patients, the frequency of positive responses was significantly higher than in normals in all assays. However, in the clinical situation, liver cancer patients have to be differentiated from patients with other liver diseases, especially cirrhosis and chronic active hepatitis, rather than from normal subjects. When HCC patients were compared to cirrhosis/ chronic active hepatitis patients in the frequency of AFP positivity, the most discriminating assay was CIE $\left(\chi^{2}=61 \cdot 1\right)$. It also had a low 'false positive' detection rate $(3 \cdot 6 \%)$ and a sensitivity of $71.9 \%$. Immunodiffusion was lowest in 'false positives'
$(1.9 \%)$ but was also the least sensitive $(56.2 \%)$ assay. Supplement CIE and RIA were the most sensitive assays but also had high 'false positive' rates $(22.5 \%$ and $15.9 \%$ respectively).

\section{Discussion}

Of the four assays used for detecting AFP, counterimmunoelectrophoresis appeared to be the best for differentiating liver cancer from cirrhosis and chronic active hepatitis. It had the highest $\chi^{2}$ value, the sensitivity of the assay was reasonably high $(71.9 \%)$, and the 'false detection' rate was low (3.6\%). This conclusion is essentially similar to that of Kohn and Weaver. ${ }^{3}$ This assay should be useful for routine laboratory diagnostic work. Other important factors are low running cost, speed of assay, and adaptability for use in field conditions. These are important factors, especially in developing countries, and it is in these countries that the incidence of primary hepatocellular carcinoma is highest.

This work was supported in part by contract No. N01-CP-43296 of the Virus Cancer Program of the National Cancer Institute, NIH, USA, and in part by a grant from the Ministry of Health, Singapore. We are grateful to the colleagues who referred some of the patients.

\section{References}

${ }^{1}$ Norgaard-Pedersen B. Human alpha-fetoprotein-review of recent methodological and clinical studies. Scand $J$ Immunology Suppl No. 4, 1976;7-45.

${ }^{2}$ Chan SH, Heng SH, Simons MJ. Detection of AFP by supplementation counterimmunoelectrophoresis (CIE) method. J Immunol Methods 1979;29:191-6.

${ }^{3}$ Kohn J, Weaver PC. Serum alpha-fetoprotein in hepatocellular carcinoma. Lancet 1974;2:334-7.

Requests for reprints to: Dr SH Chan, WHO Immunology Research and Training Centre, Faculty of Medicine, University of Singapore, Sepoy Lines, Singapore 0316, Republic of Singapore.

Frequency of AFP positivity by different assays in patients with liver diseases and in normal subjects

\begin{tabular}{|c|c|c|c|c|}
\hline \multirow[t]{2}{*}{ Patient group } & \multicolumn{4}{|l|}{ Assay } \\
\hline & $I D$ & $C I E$ & Suppl. CIE & $\boldsymbol{R I A}$ \\
\hline $\begin{array}{l}\text { HCC } \\
\text { CAH } \\
\text { Cirrhosis } \\
\text { CAH and cirrhosis } \\
\text { Acute viral hepatitis } \\
\text { Normal }\end{array}$ & $\begin{array}{c}* 50 / 89(56 \cdot 2) \\
0 / 35(0) \\
1 / 18(5 \cdot 6) \\
1 / 53(1 \cdot 9) \\
0 / 67(0) \\
0 / 56(0)\end{array}$ & $\begin{array}{l}64 / 89(71 \cdot 9) \\
0 / 25(0) \\
2 / 30(6 \cdot 7) \\
2 / 55(3 \cdot 6) \\
1 / 50(2 \cdot 0) \\
0 / 30(0)\end{array}$ & $\begin{array}{l}45 / 55(81 \cdot 8) \\
11 / 37(29 \cdot 7) \\
5 / 34(14 \cdot 7) \\
16 / 71(22 \cdot 5) \\
5 / 50(10 \cdot 0) \\
0 / 30(0)\end{array}$ & $\begin{array}{l}70 / 89(78 \cdot 7) \\
3 / 20(15 \cdot 0) \\
4 / 24(16 \cdot 7) \\
7 / 44(15.9) \\
6 / 32(18 \cdot 8) \\
0 / 40(0)\end{array}$ \\
\hline
\end{tabular}

* Number positive/Number tested (\%). 